\title{
Effect of the Asset Quality on the Bank Profitability
}

\author{
Eyup Kadioglu ${ }^{1}$, Niyazi Telceken ${ }^{1} \&$ Nurcan Ocal ${ }^{1}$ \\ ${ }^{1}$ Capital Markets Board, Investor Compensation Center, Ankara, Turkey \\ Correspondence: Niyazi Telceken, Capital Markets Board, Ankara, Turkey. E-mail: ntelceken@ gmail.com
}

Received: April 13, 2017

Accepted: May 6, 2017

Online Published: May 30, 2017

doi:10.5539/ijef.v9n7p60

URL: https://doi.org/10.5539/ijef.v9n7p60

\begin{abstract}
This study investigates whether non-performing loans effect the bank's profitability in Turkey. The study applies a panel regression method to the quarterly data set including 1809 observation belongs to 55 Banks in Turkey during the period from $1^{\text {st }}$ quarter of 2005 to $3^{\text {rd }}$ quarter of 2016. It is found that there is a significant, negative relationship between non-performing loans and bank profitability which is measured by return on equity and return on asset. The higher non-performing loans, the lower asset quality, leads to the lower return on equity and return on asset, and the lower non-performing loans, the higher asset quality, leads to the higher return on equity and return on asset.
\end{abstract}

Keywords: asset quality, non-performing loans, bank profitability, Turkish banking sector

\section{Introduction}

Although the asset quality is important for all companies, it has significant importance on profitability of banks that are crucial components of financial markets and proper process of the banking operations as well as the financial system and accordingly national economy. Asset quality in banks is related to the quality of loans provided by the bank and the quality of loans can be measured with the non-performing loan (NPL) where NPL consist of overdue loans and follow-up loans.

According to Bernanke, Lown, and Friedman (1991), non-performing loans or lower asset quality, in economies that have bank based financial systems which is also known as "credit crunch", may defer economical recovery by decreasing operating profit margin or eroding capital base for new loans. For Klein (2013), non-performing loans will effect profitability of banks which is their main profit source and ultimately financial stability of economy. Lower asset quality or non-performing loans reaching substantial amount may lead to bank bankruptcies and economic slowdown (Adhikary, 2006; Barr \& Siems, 1994; Berger \& DeYoung, 1997; Demirguc-Kunt, 1989; Whalen, 1991). Considering that one of the main reasons for 2008 global crisis is lower quality assets, which can be defined as toxic assets, measuring non-performing loans, analyzing their effects well and producing required economic policies have significant importance for whole economy as well as the banks themselves.

Accordingly, especially within last 25 years, regulations are put in to effect by national and international institutions in order to determine asset quality with regards to the importance of it. In 1995 at the United States of America, United States Federal Reserve Board bring "Standards for safety and soundness" into force which stipulates regular reporting obligation on asset quality for board of directors of banks in order to evaluate the risks on deformation of asset quality and to form asset quality supervision systems by financial institutions in order to define problems that may arise with regards to asset quality (Eze \& Ogbulu, 2016).

7 of the 25 fundamental principles determined, by Basel Committee on Banking Supervision (BCBS), for the effective supervision of banking system are related with the asset quality of bank and loan risk management and this indicates that the asset quality become an important aspect for supervision authorities of each country worldwide (Abata, 2014). Hence, criteria which are started to be published by BCBS in 2000 titled Basel I are legalized by European Union with the directives on capital adequacy. The mentioned criteria are revised in accordance with the developments on financial markets and global financial crisis started as of the end of the 2007. Lastly, Basel III criteria are put in effect in 2013.

The studies of Abata (2014), Pasiouras and Kosmidou (2007), Adebisi and Matthew (2015), Bace (2016), Bhattarai (2016), Kiran and Jones (2016), Taşkın (2011), Akbaş (2012), Miller and Noulas (1996), Duraj and Moci (2015), Etale, Ayunku, and Etale (2016), Güneş (2015), Hashem (2016), Ongore and Kusa (2013), Ozgur 
and Gorus (2016), Ozurumba (2016), Sarıtaş, Uyar, and Gökçe (2016) are examples of lower asset quality or non-performing loans affecting profitability of banks negatively. On the other hand, where Adebisi and Matthew (2015), Güneş (2015), Samırkaş, Evci, and Ergün (2014) did not come up with a correlation between Return on Equity (ROE) and NPL; Afiriyie and Akotey (2013) and Bhattarai (2016) found positive correlation between ROE and NPL and Buchory (2015) found positive correlation between Return on Assets (ROA) and NPL.

Within the scope of this study, the effect of the asset quality (non-performing loans) on bank profitability (ROE or ROA) is investigated for Turkish banking sector. In this manner, quarterly solo financial statements, prepared in accordance with International Financial Reporting Standards (IFRS), that belong to the period from $1^{\text {st }}$ quarter of 2005 to $3^{\text {rd }}$ quarter of 2016, of 55 banks operating in Turkish banking sector is observed. Panel regression method is used to determine the relationship between "the ratio of the follow-up loans to asset" and "ratio of provisions for overdue loans to total loans" which are independent variables and ROA/ROE which are dependent variables. Our study, under which the effect of non-performing loans to bank profitability is investigated, separates from the other studies made for Turkey as it compromises of two different variables at the same time and as it directly measures the effect of non-performing loans to bank profitability and it uses recent and quarterly data.

As per the results of bilateral fixed effect panel regression analysis; negative relationship between variable ROA/ROE, indicating the bank profitability, and "the ratio of the follow-up loans to asset" and "ratio of provisions for overdue loans to total loans" measuring the asset quality is identified. Under Turkish banking sector, increase of non-performing loans decreases the bank profitability and decrease of the non-performing loans increases bank profitability.

Literature summary is provided hereinafter of this study and under third section information on data and method is provided and within the scope of fourth section, empirical results are defined. The fifth and the last section of this study comprises of result and suggestions.

\section{Literature Review}

As known, the main asset effecting the asset quality negatively in banks is the non-performing loans. Mainly, non-performing loans arises in cases where the principal or interest amounts of loans provided by banks are not paid back as planned.

In Basel criteria determined by Basel Committee within the scope of effective supervision of banking sector, asset quality is measured regarding the capital adequacy. In that, within the scope of regulations of Basel on capital adequacy, in order to measure capability of a bank to solvency, the ratio of capital to risk weighted assets is used and this ratio is expected to be at least $8 \%$. Weighting of assets in accordance with the risk means elimination of possible impairment in assets and accordingly increase of the asset quality. While measuring asset quality prudentially, it is possible to use risk weighting approach in order to measure asset quality pertaining to previous periods non-performing loans can be taken into consideration. While the high amounts of non-performing loans indicate the lower asset quality; lower amounts non-performing loans indicates higher asset quality. By Adhikary (2006), inadequate audit and supervision function, lack of required regulations and lack of effective debt improvement strategies are shown with regards to the reasons of non-performing loans.

Choudhury and Adhikary (2002) states that non-performing loans are not in one type and they can be categorized under different groups according to the time period elapsed following their due date. Non-performing loans are not basic results of loan providing process but accepted as a typical by-results of financial crisis. However, non-performing loans have substantial potential on increasing severeness and duration of financial crisis and complicating macroeconomic management in cases they are arising from providing loans process coincidentally. Hence, non-performing loans may result with the loss of trust of investors to banking system and accumulation of nonproductive economical sources and collapse of resource allocation process (Woo, 2000) .

Non-performing loans which are created by barrowers on purpose and left unsettled may result with contagious financial fragility by alienating good barrowers. According to Muniappan (2002) non-performing loans effects not only the profitability of banks by way of bearing costs of an asset that is not able to provide income but also negatively effects the capital adequacy.

Non-performing loans leads bank management to waste too much time and effort. This situation is an indirect cost that the bank has to bear as a result of low asset quality. Non-performing loans not only causes lack of interest income but also effects future profit flows by resulting with the loss of opportunity on realizing some investments with return. Additionally, non-performing loans have risk to damage reputation of banks. Increase of non-performing loans and non-performing loans reached to a substantial amount, limit the opportunities of 
co-financing and syndication of the bank that may be realized with other banks by effecting negatively the credit rating of the bank beside the bank profitability. Although, the relationship between profitability and non-performing loans is not clear (Bhattarai, 2016).

Although there are on-going efforts on controlling activities of banks on loan providing, non-performing loans constitutes main concern of both international and national regulatory authorities. As per the report published by IMF on 2007, the ratio of total non-performing loans differ radically between countries especially between developing countries and developed countries (Boudriga, Boulila Taktak, \& Jellouli, 2009, p. 287). While countries like Egypt, Nigeria, Philippines, Morocco, Algeria, and Tunisia (more than 15\%) have trouble on low quality loans; there are no impressions indicating that the countries like Sweden, Norway, Finland, Australia, and Spain (less than 1\%) have trouble arising from the erosion of asset quality. Beside, in recent years, significant number of studies concentrated on key role of asset quality on estimation of bank failure (Barr \& Siems, 1994; Berger \& DeYoung, 1997; Demirguc-Kunt, 1989; Whalen, 1991) .

Besides the studies regarding the effect of non-performing loans on bank profitability, there are numerous studies considering non-performing loans as explanatory variable in aspects determining bank profitability and stipulating the relationship between NPL and profitability. Under studies of Abata (2014), Pasiouras and Kosmidou (2007), Adebisi and Matthew (2015), Bace (2016), Bhattarai (2016), Kiran and Jones (2016), Taşkın (2011), Miller and Noulas (1996), Duraj and Moci (2015), Etale et al. (2016), Hashem (2016), Ongore and Kusa (2013), Ozurumba (2016), testing the correlation between NPL and profitability, negative relationship is determined between non-performing loans decreasing the asset quality and bank profitability. On the other hand, where Adebisi and Matthew (2015), did not come up with a relationship between ROE and NPL; Afiriyie and Akotey (2013), Bhattarai (2016) found positive relationship between ROE and NPL and Buchory (2015) found positive relationship between ROA and NPL.

To our best knowledge, although there is no study investigated directly effect of asset quality on bank profitability under studies conducted with regards to Turkey, there are studies, accepting non-performing loans as one of the explanatory variable, which conducted on investigation of factors determining bank profitability.

Under the study of Taşkın (2011) and Akbaş (2012), on factors determining the bank profitability, accepted ratio of loan loss provisions to asset as the measure of non-performing loans where Sarıtaş et al. (2016) accepted ratio of non-performing loans to asset as the measure of it. Within the scope of all these studies, variables of ROE or ROA are taken into consideration as the measure of bank profitability and as a result negative relationship is found between non-performing loans and ROA and ROE. Ozgur and Gorus (2016) accepted the ratio of non-performing loans to total cash loans as the measure of non-performing loans and found negative relationship between ROA and NPL.

Within the scope of study conducted by Güneş (2015) and Samırkaş et al. (2014) no relationship is found between non-performing loans beside the other factors and ROE and ROA.

\section{Data and Methodology}

\subsection{Data}

In this study quarterly solo financial statements prepared in accordance with IFRS, that belong to the period from $1^{\text {st }}$ quarter of 2005 to $3^{\text {rd }}$ quarter of 2016, of 55 banks operating in Turkish banking sector is used and there are 1809 observations.

The data used is obtained from public database of The Banks Association of Turkey. Within the scope of our study, data of deposit banks are used beside the data of investment and participation (Turkish type of Islamic banking) banks. Accordingly, number of banks used by years are as follows.

Table 1 . Number of banks and types sampled by years

\begin{tabular}{|c|c|c|c|c|c|c|c|c|c|c|c|c|}
\hline Bank Type & 2005 & 2006 & 2007 & 2008 & 2009 & 2010 & 2011 & 2012 & 2013 & 2014 & 2015 & 2016 \\
\hline Deposit & 34 & 33 & 32 & 32 & 32 & 32 & 32 & 32 & 32 & 32 & 34 & 34 \\
\hline Investment & 12 & 12 & 12 & 12 & 12 & 12 & 12 & 12 & 12 & 12 & 12 & 12 \\
\hline Participation & 4 & 4 & 4 & 4 & 4 & 4 & 4 & 4 & 4 & 4 & 4 & 6 \\
\hline Total & 50 & 49 & 48 & 48 & 48 & 48 & 48 & 48 & 48 & 48 & $\mathbf{5 0}$ & 52 \\
\hline
\end{tabular}

As it is shown under Table 1; circa 50 banks comprise of 12 banks which are investment banks and 4 banks (6 in 2016) which are participation banks. 


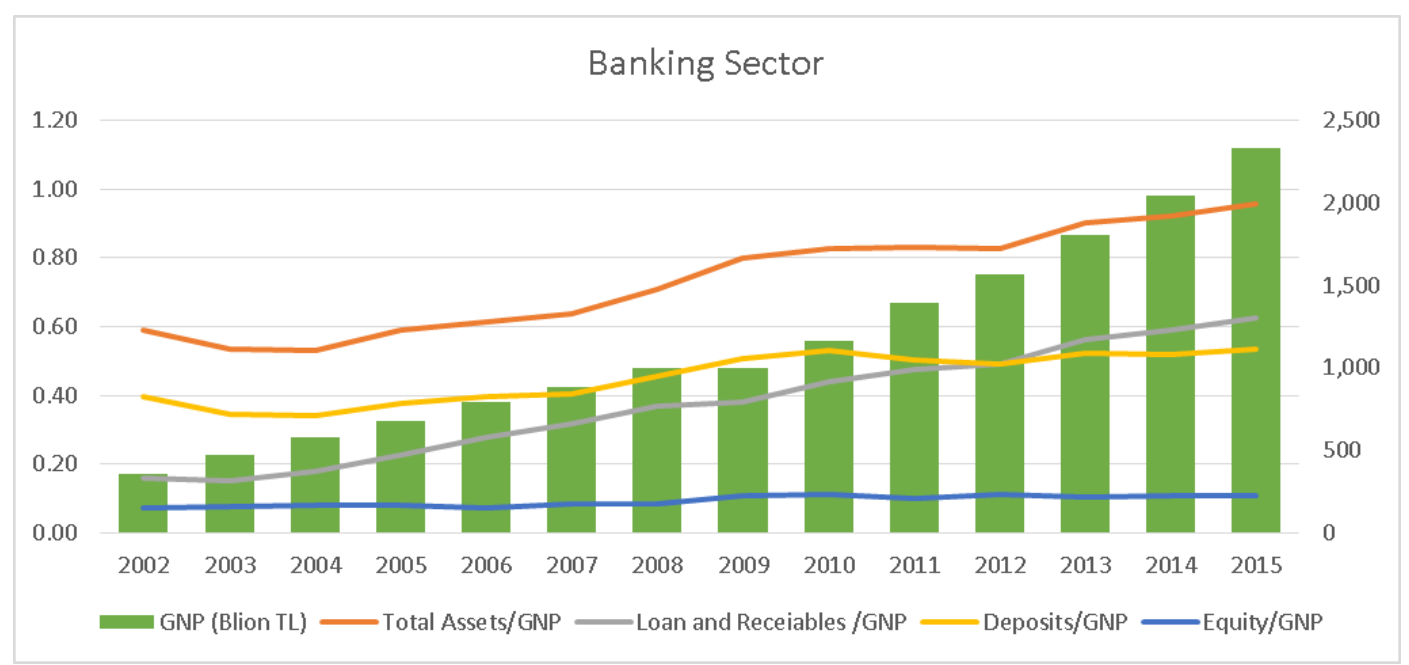

Figure 1. Basic indicators of Turkish banking sector

As shown under Figure 1; it is understood that loans are increased in parallel with the increase in Gross Domestic Product (GDP) as of 2002. From 2002 to the end of 2015 GDP increase 6.5 times where bank loans and receivables increased 4 times and deposits increased 1.35 times. Ratio of asset size of Turkish banking sector to GDP increased from 0.6 to 0.95 .

Variables considered within the scope of this study is calculated with regards to balance sheet and income statement accounts stated below.

Table 2. Variables used within the scope of this study

\begin{tabular}{|c|c|c|c|}
\hline Variable & & Type & Formula \\
\hline$R O E$ & $:$ & Dependent & Net Profit/Equity \\
\hline$R O A$ & : & Dependent & Net Profit/Total Asset \\
\hline$T K 2 T A$ & : & Independent & Non-performing (follow-up) loans /Total Asset \\
\hline$P R O 2 L$ & : & Independent & Provisions for non-performing (overdue) loans/Total Loan \\
\hline$E Q 2 T A$ & : & Independent Control & Total Equity/Total Assets \\
\hline
\end{tabular}

Equity profitability $(R O E)$ and asset profitability $(R O A)$ is used for bank profitability as like with numerous studies (Adebisi \& Matthew, 2015; Bhattarai, 2016; Güneş, 2015; Ozgur \& Gorus, 2016; Sevim \& Eyüboğlu, 2016; Taşkın, 2011). Variable $E Q 2 T A$, the ratio of equity total to asset total is used for controlling equity size of the bank where the dependent variable is $R O E$ and used for controlling asset size of the bank where the dependent variable is $R O A$.

Descriptive statistics regarding the data used under our study is indicated under Table 3 as follows.

Table 3. Descriptive statistics

\begin{tabular}{llllll}
\hline & PRO2L & TK2TA & EQ2TA & ROA & ROE \\
\hline Mean & 0.028 & 0.027 & 0.242 & 0.012 & 0.061 \\
Median & 0.000 & 0.019 & 0.136 & 0.010 & 0.055 \\
Maximum & 7.839 & 0.593 & 0.991 & 0.322 & 0.454 \\
Minimum & 0.000 & 0.000 & 0.016 & -0.214 & -1.786 \\
Std. Dev. & 0.317 & 0.033 & 0.226 & 0.025 & 0.099 \\
Observations & 1,809 & 1,809 & 1,809 & 1,809 & 1,809 \\
\hline
\end{tabular}

Table 3 stipulates descriptive statistics of variables used within the study. The values like average, median, maximum and standard deviation of 1809 observations of 55 banks and 12 years are indicated under this table.

Correlation matrix is stated under Table 4 in order to understand the measure of covariation of variables. 
Table 4. Correlation between variables

\begin{tabular}{lccccc}
\hline & PRO2L & TK2TA & EQ2TA & ROA & ROE \\
\hline PRO2L & 1.00 & & & & \\
TK2TA & 0.25 & 1.00 & 1.00 & & \\
EQ2TA & 0.24 & 0.29 & 0.25 & 1.00 & 1.00 \\
ROA & -0.08 & 0.05 & -0.13 & 0.61 & \\
ROE & -0.06 & -0.12 & & & \\
\hline
\end{tabular}

As it is shown under Table 4, correlation coefficient between variables are in acceptable levels. Especially, the parameter of 0.25 between the ratio of non-performing (follow-up) loans to asset (TK2TA) and provisions for non-performing (overdue) loans to total loans $(P R O 2 L)$ indicates that there will be no multicollinearity problem. These two variables measure loan quality, in other words non-performing loans, from different point of views. The overdue loans are pre-phase of the follow-up loans and they contain possibility to turn into follow-up loans.

\subsection{Methodology}

Under our study, effect of non-performing loans to bank profitability is investigated for Turkish banking sector. Within this scope, predictions are made by panel regression analysis with the below stated equation by using quarterly financial statements data between the period of 2005-2016 of 55 banks operating in Turkey. This equation and close versions are used also by Ozurumba (2016), Ugoani (2016), Adebisi and Matthew (2015), Bhattarai (2016), Etale et al. (2016), Lata (2014), Afiriyie and Akotey (2013) and Bace (2016). Likewise, by searching non-performing loans as the determinants of bank profitability under their studies, more extensive forms of the below stated equation is used (Buchory, 2015; Duraj \& Moci, 2015; Güneş, 2015; Kasavica \& Jović, 2015; Khan, Anuar, Choo, \& Khan, 2011; Ozgur \& Gorus; Samırkaş et al.; Sarıtaş et al.; Taşkın, 2011)

$$
\begin{aligned}
& R O E_{i, t}=\alpha+\beta_{1} \text { TK2TA }_{i, t}+\beta_{2} P R O 2 L_{i, t}+\beta_{3} E Q 2 T A_{i, t}+\varepsilon_{i, t} \\
& R O A_{i, t}=\alpha+\beta_{1} \text { TK2TA }_{i, t}+\beta_{2} P_{R O 2 L_{i, t}}+\beta_{3} E Q 2 T A_{i, t}+\varepsilon_{i, t}
\end{aligned}
$$

Here, $R O E_{i, t}$ indicates the return on equity of the bank $i$ in $t$ year, $R O A_{i, t}$ indicates the return on asset of the bank $i$ in $t$ year, $P R O 2 L_{i, t}$ indicates the ratio of provisions of non-performing (overdue) loans to total loans of the bank $i$ in $t$ year, $T K 2 T A_{i, t}$ indicates the ratio of non-performing (follow-up) loans to asset of the bank $i$ in $t$ year and $E Q 2 T A_{i, t}$ indicates the ratio of equity to asset of the bank $i$ in $t$ year.

Below stated hypothesis are use under our study in order to test effect of non-performing loans to bank profitability.

H1: Non-performing loans effect bank profitability negatively.

H1a: Provisions for non-performing (overdue) loans effects bank profitability negatively.

H1b: Non-performing loans (follow-up) effect bank profitability negatively.

\section{Empirical Results}

Under empirical studies, analysis is made with the assumption that the data are stationary. On the other hand, sometimes, it is known that the data, including the panel data, are not stationary in other words, they have unit root. According to some researchers, data not being stationary or that have unit root, causes variable to have non-constant mean over time. This situation, results with the high autocorrelation problem beside being low Durbin-Watson statistic at the same time (Kutty, 2010).

In this study, all variables tested for unit root. In this manner, unit root tests of Levin, Lin, and Chu (2002), Im, Pesaran, and Shin (2003), Phillips and Perron (1988) and Augmented Dickey and Fuller (1979) are used. Results of unit root test is indicated under Table 5.

Table 5. Unit root tests results

\begin{tabular}{llcccc}
\hline Variables & & ADF - Fisher Chi-square & Im, Pesaran and Shin W-stat & Levin, Lin \& Chu & PP - Fisher Chi-square \\
\hline \multirow{2}{*}{ EQ2 $\boldsymbol{N} \boldsymbol{A}$} & Stat. & 288.48 & -8.70 & -7.56 & 298.81 \\
& Pr. & 0.00 & 0.00 & 0.00 & 0.00 \\
\multirow{2}{*}{$\boldsymbol{O} \boldsymbol{A}$} & Stat. & 330.94 & -9.96 & -2.59 & 871.72 \\
& Pr. & 0.00 & 0.00 & 0.00 & 0.00 \\
\multirow{2}{*}{$\boldsymbol{O} \boldsymbol{E}$} & Stat. & 238.67 & -6.45 & -0.11 & 857.60 \\
& Pr. & 0.00 & 0.00 & 0.46 & 0.00 \\
\hline
\end{tabular}




\begin{tabular}{llcccc}
\hline \multirow{2}{*}{ TK2TA } & Stat. & 157.71 & -3.45 & -5.06 & 160.95 \\
& Pr. & 0.00 & 0.00 & 0.00 & 0.00 \\
\multirow{2}{*}{ PRO2L } & Stat. & 288.78 & -11.81 & -20.31 & 368.39 \\
& Pr. & 0.00 & 0.00 & 0.00 & 0.00 \\
\hline
\end{tabular}

Note. Probability value being lower than $5 \%$ shows that the hypothesis $\mathrm{H}_{0}$, of "there is root unit" is rejected.

As it is understood from Table 5, variables used within the scope of our study are stationary. Hence, probability value of the test results of at least three from four different tests are statistically significant at the rate of $1 \%$.

Results of equation used in order to test effect of non-performing loans to bank profitability is indicated under Table 6. Under Table 6, separate estimations are made for $R O A$ and $R O E$ which are accepted as dependent variables for measuring the effect of non-performing loans to bank profitability.

Table 6. Results of two-way fixed effect panel regression

\begin{tabular}{lcccc}
\hline \multirow{2}{*}{ Variable } & \multicolumn{2}{c}{ Dependent Variable: ROE } & \multicolumn{2}{c}{ Dependent Variable: ROA } \\
\cline { 2 - 5 } Coefficient & T-statistics & Coefficient & T-statistics \\
\hline $\boldsymbol{T K 2 T A}$ & 0.067 & $0.000^{*}$ & 0.000 & 0.908 \\
PRO2L & -0.647 & $0.000^{*}$ & -0.126 & $0.000^{*}$ \\
$\boldsymbol{E Q 2 T A}$ & 0.001 & 0.936 & -0.015 & $0.000^{*}$ \\
F-statistics & 0.046 & $0.015^{* *}$ & 0.065 & $0.000^{*}$ \\
Adj R & & & & $18.14^{*}$ \\
\hline
\end{tabular}

Note. ${ }^{*}$ indicates $1 \%$ significance level and ${ }^{* *}$ indicates $5 \%$ significance level. The results of Lagrange Multiplier Tests for Random Effects stipulate that the analysis shall be made with panel regression. Hausman test is realized over one way random effect model as of the lack of observation resulting that our data is unbalanced. Hausman test suggested fixed effect model.

The estimation results under Table 6, variability of $R O E$ and $R O A$, respectively $30 \%$ and $47 \%$, can be explained by the variability of the dependents variables, the ratio of non-performing loans (follow-up) to assets, the ratio of provisions for non-performing (overdue) loans to total loans and the control dependent variable equity to asset. $F$ statistic indicating the overall statistical significance level of the models is $1 \%$.

Again, as stated under Table 6, there is negative relationship between TK2TA with ROE and ROA at the 1\% significance level. Increase of non-performing (follow-up) loans in the total assets, negatively effects the bank profitability. Decrease of non-performing (follow-up) loans in the total assets, increases the bank profitability. Likewise, there is negative significant relation between $P R O 2 L$ and $R O A$ at the $1 \%$ significance level. While the increase in provisions for non-performing (overdue) loans to total loans effects profitability negatively; decrease in provisions for non-performing (overdue) loans to total loans increases bank profitability.

The equity to asset ratio that is included to the equation as a control variable is in positive correlation with $R O E$ at the 5\% significance level, is in positive correlation ROA at the $1 \%$ significance level. It can be concluded that using equity while financing assets effects profitability positively.

The results comprising relationship between non-performing loans and profitability are in line with the results of studies conducted by Abata (2014), Pasiouras and Kosmidou (2007), Adebisi and Matthew (2015), Bace (2016), Bhattarai (2016), Kiran and Jones (2016), Taşkın (2011), Miller and Noulas (1996), Duraj and Moci (2015), Etale et al. (2016), Hashem (2016), Ongore and Kusa (2013) and Ozurumba (2016), and are not in line with the results of studies conducted by Afiriyie and Akotey (2013), Bhattarai (2016) and Buchory (2015).

\section{Conclusion}

As the asset quality of banks has significant importance on financial system of the country and accordingly to national economy besides its effects to bank profitability; it is required to measure, oversee, examine effectively of the impacts of non-performing loans and accordingly to initiate effective economic policies. Within this scope, especially during last quarter century, regulations or criteria, aiming to ensure high asset quality, put in force by both national and international organizations and risk models developed with regards to this issue.

There are numerous studies in literature investigating directly the effect of non-performing loans to bank profitability beside the studies taking non-performing loans as explanatory variable among the determinants of bank profitability and executing the relationship between NPL and profitability. Despite counter findings, 
throughout the studies, it is revealed that non-performing loans effects bank profitability negatively.

Under this study, whether there is relationship or not between non-performing loans (asset quality) and bank profitability (return on equity or return on asset) investigated for Turkish banking sector. In this study, quarterly solo financial statements prepared in accordance with IFRS, that belong to the period from $1^{\text {st }}$ quarter of 2005 to $3^{\text {rd }}$ quarter of 2016, of 55 banks operating in Turkish banking sector is used. While investigating the relationship in question, asset quality is measured with the ratio of non-performing (follow-up) loans to total assets and ratio of provision for non-performing (overdue) loans to total loans and these independent variables are used in order to explain bank profitability.

In accordance with the results obtained from two-way fixed effect panel regression analysis; with significant negative relationship is found between the ratio of ROA/ROE variable indicating the bank profitability and non-performing loans indicating the asset quality. It is found that in Turkish banking sector, increase of the non-performing loans decreases bank profitability and decrease of the non-performing loans increases bank profitability.

As it is mentioned that asset quality may affect economic growth as well as the bank profitability; it will be beneficial to investigate correlation between asset quality and economic growth for Turkey.

\section{References}

Abata, M. A. (2014). Asset Quality And Bank Performance: A Study of Commercial Banks in Nigeria. Research Journal of Finance and Accounting, 5(18), 39-44.

Adebisi, J. F., \& Matthew, O. B. (2015). The Impact of Non-Performing Loans on Firm Profitability: A Focus on the Nigerian Banking Industry. American Research Journal of Business and Management, 1(4), 1-7.

Adhikary, B. K. (2006). Nonperforming loans in the banking sector of Bangladesh: Realities and challenges. Bangladesh Institute of Bank Management, 75-95.

Afiriyie, H., \& Akotey, D. O. (2013). Credit risk management and profitability of rural banks in the brong Ahafa region of Ghana. European journal of business and management, 5(24), 24-33.

Akbaş, H. E. (2012). Determinants of bank profitability: An investigation on Turkish banking sector. Öneri Dergisi, 10(37), 103-110.

Bace, E. (2016). Bank profitability:Liquidity, capital and asset quality. Journal of Risk Management in Financial Institutions, 9(4), 327-331.

Barr, R. S., \& Siems, T. F. (1994). Predicting bank failure using DEA to quantify management quality. Dallas.

Berger, A. N., \& DeYoung, R. (1997). Problem loans and cost efficiency in commercial banks. Journal of Banking \& Finance, 21(6), 849-870. https://doi.org/10.1016/S0378-4266(97)00003-4

Bernanke, B. S., Lown, C. S., \& Friedman, B. M. (1991). The credit crunch. Brookings Papers on Economic Activity, 1991(2), 205-247. https://doi.org/10.2307/2534592

Bhattarai, Y. R. (2016). Effect of Non-Performing Loan on the Profitability of Commercial Banks in Nepal. The International Journal Of Business \& Management, 4(6), 435-442.

Boudriga, A., Boulila, T. N., \& Jellouli, S. (2009). Banking supervision and nonperforming loans: A cross-country analysis. Journal of Financial Economic Policy, 1(4), 286-318. https://doi.org/10.1108/17576380911050043

Buchory, H. A. (2015). Banking Profitability: How does the Credit Risk and Operational Efficiency Effect? Journal of Business and Management Sciences, 3(4), 118-123. https://doi.org/10.12691/jbms-3-4-3

Choudhury, T. A., \& Adhikary, B. K. (Eds.) (2002). Loan Classification, Provisioning Requirement and Recovery Strategies: A comparative Study on Bangladesh and India.

Demirguc-Kunt, A. (1989). Deposit-Institution Failures: A Review Of Empirical Literat. Economic Review-Federal Reserve Bank of Cleveland, 25(4), 2-18.

Dickey, D. A., \& Fuller, W. A. (1979). Distribution of the Estimators for Autoregressive Time Series With a Unit Root. Journal of the American Statistical Association, 74(366), 427-431. https://doi.org/10.2307/2286348

Duraj, B., \& Moci, E. (2015). Factors Influencing the Bank Profitability-Empirical Evidence from Albania. $\begin{array}{lllll}\text { Asian Economic and } & \text { Financial } & \text { Review, } & \text { 583), }\end{array}$ https://doi.org/10.18488/journal.aefr/2015.5.3/102.3.483.494 
Etale, L. M., Ayunku, P. E., \& Etale, E. (2016). The impact of Non-performing Loans and Bank Performance in Nigeria. International Journal of Humanities and Social Science Invention, 5(4), 1-5.

Eze, G. P., \& Ogbulu, O. M. (2016). Asset Quality Management and the Performance of Deposit Money Banks in Nigeria: A Co-integration and Variance Decomposition Analysis. International Journal of Economics and Financial Research, 2(3), 41-54.

Güneş, N. (2015). Banka Kârlılığının Belirleyicileri: 2002-2012 Dönemi Türk Mevduat Bankaları Üzerine Bir İnceleme. Süleyman Demirel Üniversitesi İktisadi ve İdari Bilimler Fakültesi Dergisi, 20(3), 265-282.

Hashem, H. Y. (2016). Determinants of Egyptian Banking Sector Profitability: Time-Series Analysis from 2004-2014. International Journal of Business \& Economic Sciences Applied Research, 9(2), 73-78.

Im, K. S., Pesaran, M., \& Shin, Y. (2003). Testing for unit roots in heterogeneous panels. Journal of Econometrics, 115(1), 53-74. https://doi.org/10.1016/S0304-4076(03)00092-7

Kasavica, P., \& Jović, Z. (2015). Impact of asset quality on bank profitability: Case study. Industrija, 43(4), 105-128. https://doi.org/10.5937/industrija43-9219

Khan, F., Anuar, M. A., Choo, L. G., \& Khan, H. (2011). Determinants of bank profitability in Pakistan: A case study of Pakistani banking sector. World Applied Sciences Journal, 15(10), 1484-1493.

Kiran, K. P., \& Jones, T. M. (2016). Effect of Non Performing Assets On The Profitability of Banks - A Selective study. International Journal of Business and General Management, 5(2), 53-60.

Klein, N. (2013). Non-performing loans in CESEE: Determinants and impact on macroeconomic performance (Working Paper No. WP/13/72).

Lata, R. S. (Ed.) (2014). Non-Performing Loan and its Impact on Profitability of State owned Commercial Banks in Bangladesh: An Empirical Study.

Levin, A., Lin, C. F., \& Chu, C. S. J. (2002). Unit root tests in panel data:Asymptotic and finite-sample properties. Journal of Econometrics, 108(1), 1-24. https://doi.org/10.1016/S0304-4076(01)00098-7

Miller, S. M., \& Noulas, A. G. (1996). The technical efficiency of large bank production. Journal of Banking \& Finance, 20(3), 495-509. http://dx.doi.org/10.1016/0378-4266(95)00017-8

Muniappan, G. P. (Ed.) (2002). The NPA Overhang-Magnitude, Solutions, Legal Reforms.

Ongore, V. O., \& Kusa, G. B. (2013). Determinants of financial performance of commercial banks in Kenya. International Journal of Economics and Financial Issues, 3(1), 237-252.

Ozgur, O., \& Gorus, M. S. (2016). Determinants of Deposit Bank Profitability: Evidence from Turkey. Journal of Applied Economics \& Business Research, 6(3), 218-231.

Ozurumba, B. A. (2016). Impact of Non-Performing Loans on the Performance of Selected Commercial Banks in Nigeria. Research Journal of Finance and Accounting, 7(16), 95-109. Retrieved from http://www.iiste.org/Journals/index.php/RJFA/article/viewFile/32749/33640

Pasiouras, F., \& Kosmidou, K. (2007). Factors influencing the profitability of domestic and foreign commercial banks in the European Union. Research in International Business and Finance, 21(2), 222-237. http://dx.doi.org/10.1016/j.ribaf.2006.03.007

Phillips, P. C. B., \& Perron, P. (1988). Testing for a unit root in time series regression. Biometrika, 75(2), 335-346. https://doi.org/10.1093/biomet/75.2.335

Samırkaş, M. C., Evci, S., \& Ergün, B. (2014). Türk Bankacılık Sektöründe Karlılı̆̆ın Belirleyicileri. Kafkas Üniversitesi İktisadi ve İdari Bilimler Fakültesi Dergisi, 5(8), 117-134.

Sarıtaş, H., Uyar, K. S., \& Gökçe, A. (2016). Banka Karlılı̆̆ı ile Finansal Oranlar ve Makroekonomik Değişkenler Arasındaki İlişkilerin Sistem Dinamik Panel Veri Modeli ile Analizi: Türkiye Araştırması. Eskişehir Osmangazi Üniversitesi İ̈BF Dergisi, 11(1), 87-108.

Sevim, U., \& Eyüboğlu, K. (2016). Ticari banka performansının içsel belirleyicileri: Borsa İstanbul örneği. Doğuş Üniversitesi Dergisi, 17(2), 211-223.

Taşkın, D. F. (2011). The Factors Affecting The Performance of The Turkish Commercial Banks. Ege Akademik Bakış, 11(2), 289-298. https://doi.org/10.21121/eab.2011219572

Ugoani, J. N. N. (2016). Nonperforming loans portfolio and its effect on bank profitability in Nigeria. Independent Journal Of Management \& Productıon, 7(2), 303-319. https://doi.org/10.14807/ijmp.v7i2.406 
Whalen, G. (1991). A proportional hazards model of bank failure: An examination of its usefulness as an early warning tool. Economic Review-Federal Reserve Bank of Cleveland, 27(1), 21-31.

Woo, D. (2000). Two approaches to resolving nonperforming assets during financial crises. MF Working Papers, 2000(33), 1-41. https://doi.org/10.5089/9781451845174.001

\section{Copyrights}

Copyright for this article is retained by the author(s), with first publication rights granted to the journal.

This is an open-access article distributed under the terms and conditions of the Creative Commons Attribution license (http://creativecommons.org/licenses/by/4.0/). 